\title{
Cost of Not Maintaining a Product Configuration System
}

\author{
Jeppe Bredahl Rasmussen \\ $\mathrm{PhD}$ researcher, Technical University of Denmark, Section for Engineering Design and Product Development, \\ Produktionstorvet 2800 Kgs. Lyngby, ibrras@mek.dtu.dk \\ Anna Myrodia \\ Post-Doc, Technical University of Denmark, Operations Management Science, Produktionstorvet $2800 \mathrm{Kgs}$. \\ Lyngby, annamyr@dtu.dk \\ Lars Hvam \\ Professor, Technical University of Denmark, Operations Management Science, Produktionstorvet $2800 \mathrm{Kgs}$. \\ Lyngby, lahv@dtu.dk \\ Niels Henrik Mortensen \\ Professor, Technical University of Denmark, Section for Engineering Design and Product Development, \\ Produktionstorvet $2800 \mathrm{Kgs}$. Lyngby, nhmo@mek.dtu.dk
}

Received (26.10.2018.); Revised (27.11.2018.); Accepted (05.12.2018.)

\begin{abstract}
This article investigates the cost implications of using a not sufficiently maintained product configuration system (PCS). A case study is conducted to investigate the financial loss due to poor data quality in products sold through a not-maintained PCS. We calculated the financial loss by comparing the quotations generated by the not-maintained PCS and the quotations for the same product when the PCS was updated. The results indicate that the company has been selling the products with a miscalculated $20 \%$ lower cost than the actual one. Comparing this financial loss to the cost required to keep the PCS up-to-date, we show that the former is significantly higher than the latter. The research concludes that the realized success and benefits of utilizing a PCS are related to its maintenance and data quality.
\end{abstract}

Key words: Product Configuration System, Cost Calculation Accuracy, Benefits of Product Configuration Systems, Challenges of Product Configuration Systems, Case Study

\section{INTRODUCTION}

PCSs are information systems that support the specifications of the product configuration, as well as the creation and management of configuration knowledge [1]. Studies have reported several benefits of PCSs, such as shorter lead-time for generating specifications $[2,3]$, improved accuracy of product specifications $[1,3]$, improved control of product assortment, and less repetitive work tasks $[4,5]$. To harvest the benefits of a PCS, significant work must be undertaken, including significant cost, time and possible restructuring of product assortment and work processes [6]. There are several approaches to develop a PCS, all of which mention the importance of maintenance [7-10]. However, few studies have reported on the consequences of reduced maintenance effort. This research work uses a case study to investigate the financial consequences of not maintaining a PCS properly. To investigate these effects, the following research questions were developed:

RQ1. What are the cost implications of not maintaining a PCS?
RQ2. How do the cost implications compare to the cost of PCS ownership and maintenance?

To test the research questions, a case study was performed in a case company that had experienced major changes in its market of operation that affected its product offerings and manufacturing costs. During the change period, the case company did not pay sufficient attention to updating its PCS to reflect the new costs due to loss of competencies and a stressful market situation. After the realization that the product offerings created by the PCS were not reflecting actual costs, the company developed an updated PCS and re-calculated all contracted projects to investigate the cost difference. The discrepancies between the old and the new PCSs provided an opportunity to study 81 projects consisting of 2655 sold products and their impacts on cost estimates. The results indicate that not maintaining a product configuration system may be more costly than spending the resources to make sure the system is up to date at all times. The rest of the paper is organized as follows: Section 2 presents a literature review on PCS in relation to cost of maintenance and data quality. Next, 
section 3 presents the research method and introduces the case company. Section 4 presents the results and answers the research questions. Section 5 discusses the results and concludes.

\section{LITERATURE REVIEW}

The literature on product configuration systems (PCSs) discusses in detail the modeling process [11,12] and the benefits realized from their implementation $[4,13,14]$. More recent research focuses on the challenges of implementing PCSs [15-17]. However, the cost of not maintaining a PCS is rarely discussed. Therefore, this literature review considers the cost of maintenance of IT software in general, the benefits of updating IT systems and the challenges relating to maintenance tasks.

PCSs are a proven concept that add significant value for companies with complex configurable products. Though the decision to implement a PCS comes with the expected costs of software, training, etc., studies have shown that their return on investment $(\mathrm{ROI})$ is very high [18]. The success of information systems and technology increases organizational performance and reduces overall costs [19]. The implementation of a PCS is also considered an enabler for mass customization [20].

Therefore, the implementation of a PCS is a strategic decision towards achieving several benefits. To reach this goal, companies must not only set up the configurator and use it, but also ensure that it is updated and, in most cases, integrated with other IT systems for data exchange [21,22]. Maintaining the data in the configuration system is crucial to ensure accurate products and price calculations. The maintenance of IT systems is linked to the overall maintenance strategy of the company's management systems [23]. However, this phase is considered less important than the initial development and implementation of the software [24].

The phases of software development include requirements identification, design, implementation, test, operation, and maintenance [25]. For a PCS, the maintenance part includes updating and maintaining the system's product features and their level of detail [26]. The main challenges identified in the literature with respect to the maintenance phase of the PCS are related to the product complexity, the frequency of product changes, and the accessibility and knowledge sharing of information needed to perform the maintenance tasks [15].

Complexity is one of the main difficulties in both software development and software maintenance [27]. In terms of PCSs, the complexity of handling configuration data increases with the complexity of products. Then, the task of maintaining the PCS becomes rather challenging and timeconsuming $[28,29]$. The failure to communicate the knowledge during the maintenance phase of the PCS is considered important among manufacturing companies [15]. Lienz, Swanson and Tompkins [24] conducted a survey to analyze how companies perceive the tasks of software maintenance and enhancement. The results indicate a high demand in terms of resources and suggest that task execution is the most important management area. Maintenance tasks for implemented software are categorized into three groups: perfective, adaptive, and corrective [30]. Adaptive maintenance is performed when expected changes occur within the data or processing environment and includes activities involving both the hardware and the software [24]. Perfective maintenance is conducted to enhance system performance and eliminate inefficiencies. Related activities could include enhancing user experience, changing computational efficiency, improving documentation, etc. [24]. Corrective maintenance is performed in response to system failures, such as bug fixes $[30,31]$. Though the allocation of specific tasks into these groups is subject to the view of the user, the consequences of not performing the tasks remain the same [23]. This means that not performing a maintenance task has similar consequences concerning cost and data quality regardless of whether this task is perfective, adaptive, or corrective. Maintenance typically comprises, on average, 60 percent of the cost across a software system's life cycle [32]. However, the most important maintenance cost is related to the consequences of not updating the PCS [7,33-35]. Poor data quality has a negative impact on an organization's economic performance $[36,37]$ and efficiency, and highquality data are crucial for its success [38-41].

Costs of corrective action [31] occur when a manufacturing company cannot satisfy customers' expectations concerning time and quality. In such cases, the company allocates more resources to ensure that the delivered product satisfies the agreed-upon requirements. In terms of PCS, this involves validating the configuration data, which affects the product specification quality, lead time, and estimated prices $[28,42]$.

The economics-driven evaluation of data management decisions concerning the maintenance of data repositories is examined in terms of costs and benefits [43]. The results of this analysis indicate that even though the cost of maintaining a system can be relatively high, the economic and business benefits can justify the need. In terms of PCSs, this can be argued by considering studies on the ROI of such investments [18]. The ROI calculation includes the cost of maintaining a PCS, and the savings are still significant (e.g. 20M euro over a 5-year period) [18]. Continuous updates to the PCS are imperative to ensure the validity and accuracy of the configuration data. This leads to fewer errors in the system and, consequently, to the end product, but also prevents system failure and enhances its general acceptance [30]. Thus, the benefits of PCSs are not evaluated only in terms of usefulness, but also in terms of their impact on a company's total costs and overall performance [19].

This need to update the configuration data is driven mainly by changes in the requirements of configurable products, which often occur due to external factors, such as customers, suppliers, and legislation [29]. If the changes require a new logic or the addition of new features to the software system, then they must be specified and incorporated [44]. These changes must be communicated and updated in the PCS and other data management systems to ensure the validity and accuracy of the configuration outcomes. This may be linked to the need to have a documentation system to 
cover not only the development phase, but also the maintenance phase [45].

The benefits of maintenance support from the vendor's perspective are discussed in the literature on enterprise resource planning (ERP) systems. These benefits include operational cost reduction relating to time, reentry errors, data entry errors, and general errors in delivery [46]. The maintenance activities in ERP systems include correcting logic errors and revising or enhancing the system to satisfy user requirements [47]. Unsuccessful ERP maintenance may result in a system not achieving its potential benefits [48]. The literature discusses the cost of maintenance in detail $[47,48]$, but generally overlooks the cost implications of not maintaining the system.

Tracking and tracing all product model changes in product lifecycle management (PLM) and CAD systems is a main part of configuration management tasks [49]. In a similar way, the need to manage product data, process data, and project data is highly relevant for documentation management, especially over time and for products with long life cycles [49].

Erroneous master data, including product data, prices, and supplier data, can lead to significant costs [28]. Though the literature discusses the importance of having up-to-date and valid data [50], it has not established a link between poor data quality and monetary loss [28,51,52]. Eppler and Helfert [52] proposed a "data quality cost taxonomy" that categorizes the potential costs of poor data quality. However, there is limited research on the extent of these cost implications [28]. In conclusion, the research work discussed in this section support only indirect relations, pointing to the need to further examine the monetary consequences of not performing maintenance tasks. In particular, the cost of not updating PCS data has not been discussed or quantified. This work aims to address this research gap.

\section{RESEARCH METHOD}

The purpose of this research is to identify and evaluate the cost of not maintaining product data in a PCS. The selected research method is case study due to the ability to generate meaningful theory through observations of actual practice-which can, in turn, contribute to the enfolding of this theory. Case research studies the phenomenon in its natural setting, providing answers to questions of "Why, what, and how" [53]. Case research is particularly suitable for this area of study-which has not been investigated in depth (as discussed in the literature review section)-as it supports exploratory research with still unknown variables and not fully understood phenomena [54].

The selected case study is considered a highly representative example from the manufacturing industry, as the company designs, manufactures, and installs complex configurable products. The company supports its sales process via a PCS. The company has been using the PCS for seven years; therefore, it can be considered mature enough to be examined in this study and to provide rich data [54]. The main limitation of the single case study concerns the generalizability of the findings [54].
Data collection includes quantitative data on cost categories (salaries, materials, prices, outsourced components, etc.) from the company's configuration system, observations and semi-structured interviews with the head of sales. Semi-structured interviews are used to ensure that the interviews address the relevant aspects of this research, but also to provide the freedom to discuss emerging aspects mentioned by the experts. These different sources of data collection allow for triangulation and validation of the collected data $[55,56]$. The unit of analysis is at the project level: analyzing individual cost contributors within each project. The sample used in the case study includes 81 projects sold over the course of one year (2014). The research team had access to the company's resources for data collection for a period of six months. The following section describes the details of the case study and the collected data. Additionally, a paired statistical test for significance was performed. A Wilcoxon signed-ranks test indicated that the costs recalculated by the 2016 PCS were statistically significantly higher than those calculated by the old PCS in 2014, $Z=-7.620, p<0.01$. Of the 81 projects, the new calculation showed higher costs for 77 and lower costs for 4 .

The case company was a Scandinavian company that provided system deliveries consisting of a complete package of product, process, and legal permissions in the manufacturing industry. In 2013, the turnover was 34 million $€$, and the company employed 130 people. The company's offering was product installations and the handling of legal requirements for customers. The projects consisted of standard solutions based on a standardized product assortment from five different product families, and the time from contract to finished project was usually between half a year and two years. Every project delivery involved several different products for different customers, all of which shared some costs of initial machinery setup. The signed contracts were fixed in price and did not vary if the company had to make product changes, emphasizing the need for correct calculations. The historical cost estimations provided by the PCS had proven accurate since 2009, with only minor deviations. The company had four major expense categories: materials, salaries for workers performing the installations, sub-suppliers, and shared costs (i.e. costs shared among individual customers buying an installation). In 2017, the distribution of individual project costs were approximately as follows: salary (13\%), materials $(55 \%)$, sub-suppliers $(24 \%)$, and shared costs $(7 \%)$. The company had primarily used a PCS to generate quotations on projects since 2009.

Key employees from sales, product development, suppliers, and marketing handled the PCS to make sure offerings were correctly priced and sufficient to cover the market. In 2013, a key employee left for another company and the efforts to maintain the product assortment and corresponding PCS were no longer of primary concern to the company. Meanwhile, two years passed without significant changes from suppliers or the market, resulting in a successful and profitable business without much need for adjustments. At some point, however, competition increased and market 
requirements changed, resulting in drastically different product offerings. However, since the company no longer focused on the PCS, the sales offerings continued to carry their 2013 prices with no changes, even though salaries had been re-negotiated, materials were calculated based on different principles, and stricter requirements had increased costs. In 2015, the company realized a loss on most projects compared to the calculation and increased the costs of all products by a fixed percentage in the hope that this change would cover some of the costs not included in the old PCS. At the same time, an initiative was taken to update the PCS to fit the new structure. This initiative was completed in the beginning of 2016. To understand the difference between the sold projects configured in the PCS from 2013 and the actual prices, all projects were recalculated in the new PCS developed in 2016. A timeline of the initiatives taken between the old (2013) and new (2016) PCS is presented in Figure 1.

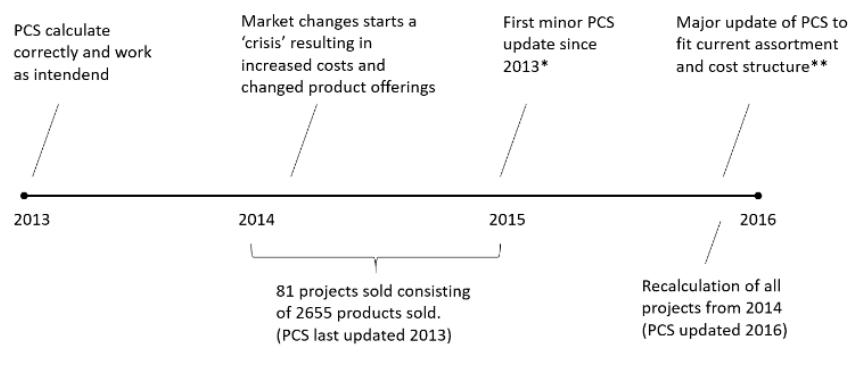

*Fixed percentage increase in costs to all parts of model, no change in product offerings
${ }_{* * *}^{*}$ Implementation reflecting new cost structure, product offerings of company and market situation (PCS 2016)

Figure 1. Timeline of initiatives taken to update PCS in the case company

The company's old and new PCS setups were roughly the same, as represented schematically in Figure 2. The PCS takes user inputs in the form of product design and work process specifications. These user inputs are then translated by an inference engine that processes the knowledge into a feasible product solution, a quotation letter, and a document with cost summaries of the specific solution. For internal use, the company generates a time estimate based on the expected salary and time needed to finalize the project in order to calculate shared costs. The cost estimate is divided into four major cost categories: salary, material, subcontractor, and shared costs.

This article compares calculations made by the old PCS in 2014 (following a drastically changed market) to recalculations of the same cases by the new PCS (implemented in the beginning of 2016 to reflect the new cost structure following changes to the market and product offerings). The basis of this comparison is the cost summary, which helps the company evaluate cost accuracy, identify billing mistakes, and improve quotations.

\section{RESULTS}

\subsection{Analysis of cost estimates in a not- maintained and a maintained PCS}

The aim of this section is to answer the first research question: What are the cost implications of not maintaining

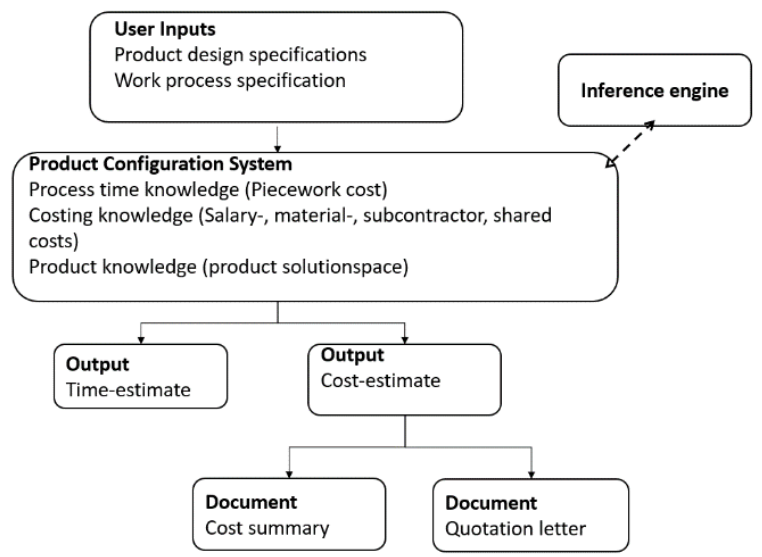

Figure 2. Product configuration system setup

the PCS? In 2014, the case company sold 81 projects, consisting of a total of 2655 individual product solutions based on the calculation principles of the 2013 PCS. The deviations were calculated both on a complete project basis and for individual cost elements. The cost difference was calculated as defined in (1), and the relative deviation was calculated as defined in (2).

CostDifference $=\mathrm{NewPCS}_{-}$calc $-\mathrm{OldPCS}_{-}$calc

$D E V=\frac{\text { Cost_Difference }}{\text { OldPCS_calc }}$

NewPCS _ calc: Raw project costs calculated on a project basis in the new PCS implemented in 2016

OldPCS_calc: Raw project costs calculated on a project basis in the old PCS implemented in 2013

CostDifference: Difference between the new 2016 PCS and old 2013 PCS calculations.

$D E V$ : Deviation in percent between the new 2016 PCS and old 2013 PCS calculations.

If the re-calculation in the new PCS is higher than the old calculation, the cost difference will be a positive number corresponding to a loss compared to the actual cost price. If the re-calculation is lower than the old calculation the result will be negative, indicating that the company would be able to deliver at a cost lower than what was sold. All numbers are calculated raw costs and outputs from the PCS and do not reflect realized costs or projects' actual profitability. The total project sum for the period was contracted at $21.6 \mathrm{M} €$ based on the old PCS and the recalculated sum was $25.8 \mathrm{M} €$, resulting in a calculation difference of $4.27 \mathrm{M} €$ (miscalculation of $20 \%$; Table 1). The individual contributors to the total cost deviation were investigated further through analyses of individual cost elements (Figure 2). According to the case company, the $21 \%$ increase in salary was due mainly to increased salaries for installation work. The $14 \%$ increase in material costs was explained by increased raw material costs and a tendency to sell products that were too simplistic for the reality of the 
changed product design. The $43 \%$ increase in supplier cost mostly came from a single contributor that was underestimated by the system compared to the actual cost charged by the supplier. Additionally, some projects needed to be changed from a simple solution sold in the old PCS to a more expensive solution that was not possible to configure or price in the old PCS. The shared cost was derived from the other costs (e.g. salary, material, and supplier costs). As these costs increased, so, too, did the shared costs. A visual comparison of the total cost calculations for all projects can be seen in Figure 3.

Table 1. Deviation in sum of total project costs from 2014 in $1000 €$

\begin{tabular}{|l|l|l|l|l|l|}
\cline { 2 - 6 } \multicolumn{1}{c|}{} & $\begin{array}{l}\text { Salary } \\
\text { cost }\end{array}$ & $\begin{array}{l}\text { Material } \\
\text { cost }\end{array}$ & $\begin{array}{l}\text { Supplier } \\
\text { cost }\end{array}$ & $\begin{array}{l}\text { Shared } \\
\text { costs }\end{array}$ & $\begin{array}{l}\text { Total } \\
\text { costs }\end{array}$ \\
\hline $\begin{array}{l}\text { New } \\
\text { calculation }\end{array}$ & 6.597 & 13.766 & 1.658 & 3.857 & 25.879 \\
\hline $\begin{array}{l}\text { Old } \\
\text { calculation }\end{array}$ & 5.458 & 12.087 & 1.156 & 2.907 & 21.609 \\
\hline Difference & 1.138 & 1.679 & 502 & 950 & 4.270 \\
\hline $\begin{array}{l}\text { Increased } \\
\text { cost (\%) }\end{array}$ & $21 \%$ & $14 \%$ & $43 \%$ & $33 \%$ & $20 \%$ \\
\hline
\end{tabular}

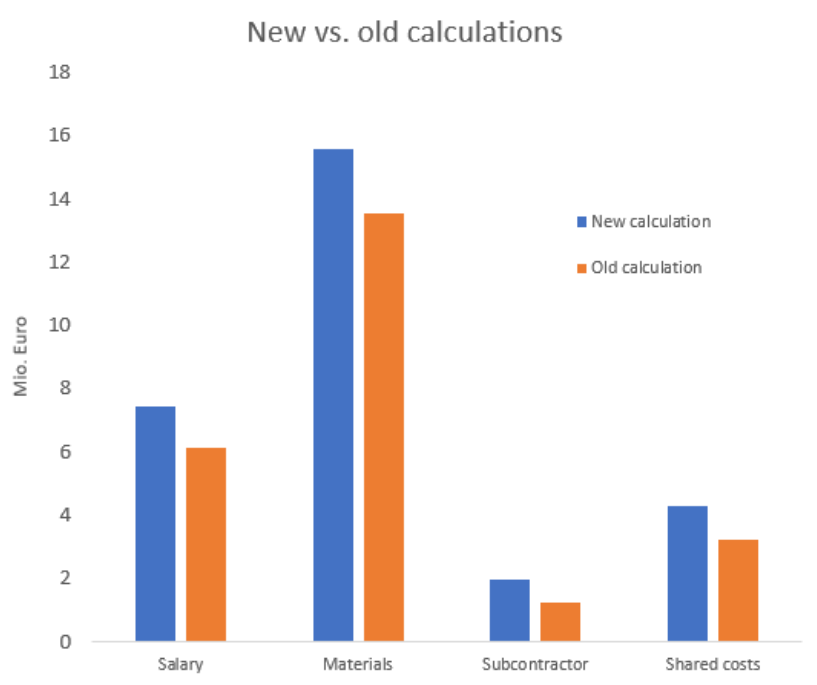

Figure 3. Comparison of calculations from new PCS and old $P C S$ in $M €$

All the projects were plotted for each cost category in a column diagram and sorted from largest deviation to smallest deviation to determine their distribution. This was done both for the absolute difference between old and new calculations (measured in euros) and in relative deviations compared to the cost of the project. Across all projects, it was observed that the larger the project, the greater the absolute deviation was. The relative deviation was primarily impacted by the execution of the project and its sub-products and, in particular, whether the project sold needed major changes compared to the solution that was initially sold.

\subsubsection{Comparison of total cost on a project basis}

The total cost difference across all projects (Figure 4) was due to a general increase in prices and changes to product structure not reflected in the old PCS. The numerical cost difference was dependent on the size of the project (i.e. bigger projects tended to have larger absolute deviations, and smaller projects tended to have smaller absolute deviations). The relative deviations were not as dependent on project size as the absolute deviations. A few projects were sold with deviations above $40 \%$, which, according to the case company, stemmed from drastic project changes due to unforeseen circumstances. Therefore, some of the worst cases might not be directly attributable to the PCS, as the increased costs could not have been known the first time the requirements changed. However, most of the following deviations can be directly related to the information stored in the PCS, since the increased costs could have been known at the time of the pricing. The projects with the biggest absolute cost difference were the same across all categories, whereas the projects with the highest deviations based on relative deviations varied more according to different cost elements.

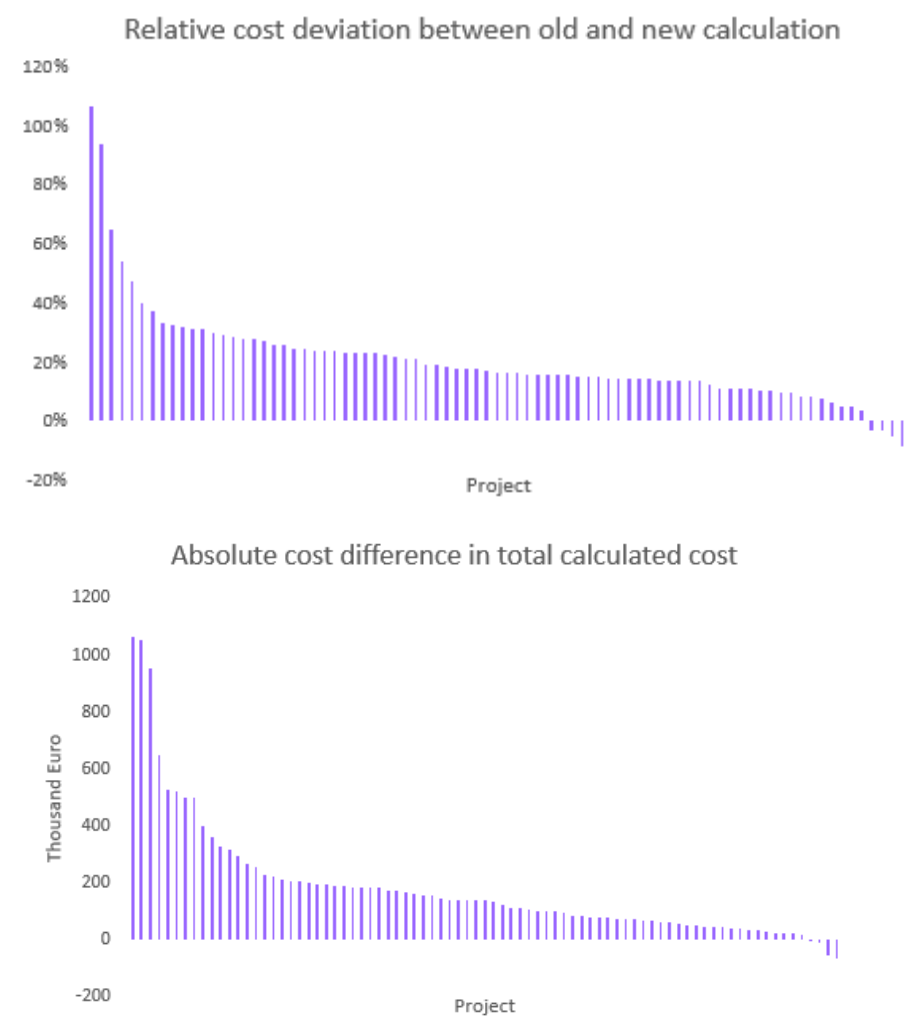

Figure 4. Absolute and relative cost deviations of 81 different projects from 2014

\subsubsection{Salary cost}

According to the case company, the difference in salary cost (Figure 5) was mainly related to increases in salary due to annual negotiations. The salary had not changed much for a long time, so the workers were able to negotiate markedly better salaries.

However, the old PCS was not updated accordingly and did not reflect the salary changes. The average increase in salaries was 21\%; however, the raise was also dependent on a case-by-case basis.

For example, some processes turned out to be more complicated than expected, resulting in a need to spend more time performing the installations. 


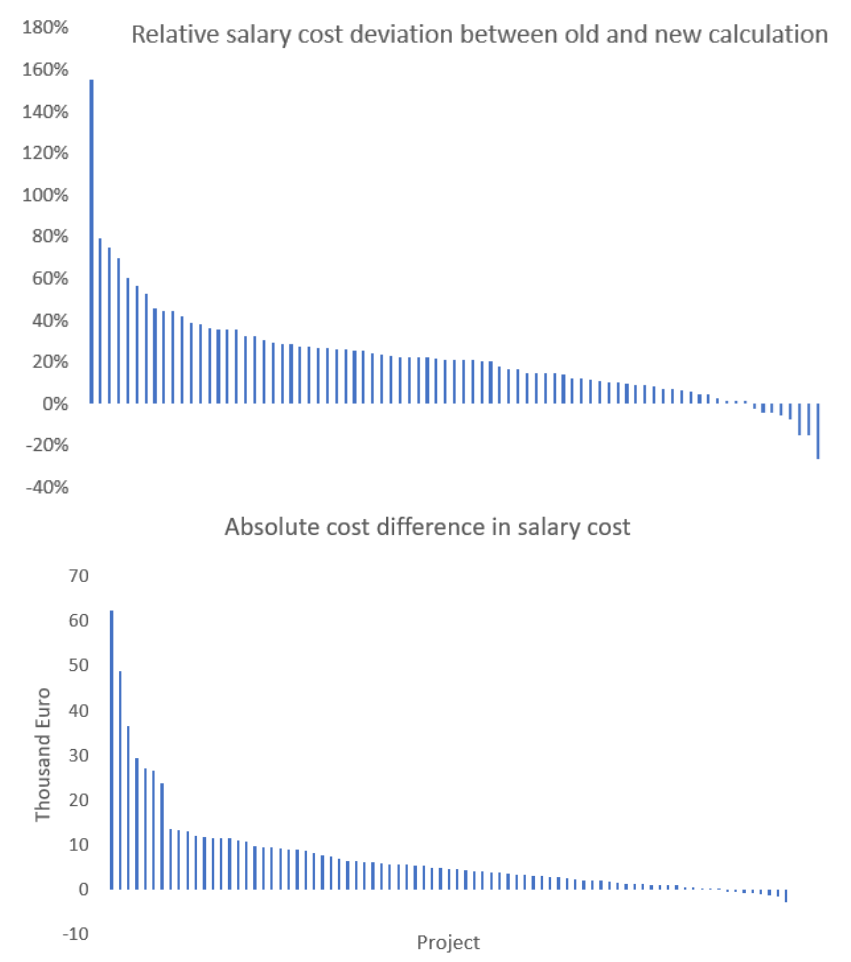

Figure 5. Absolute and relative salary cost deviation of 81 different projects from 2014

\subsubsection{Material cost}

The difference between the old and the new PCS in material cost (Figure 6) was related to changes in product design and raw material prices.
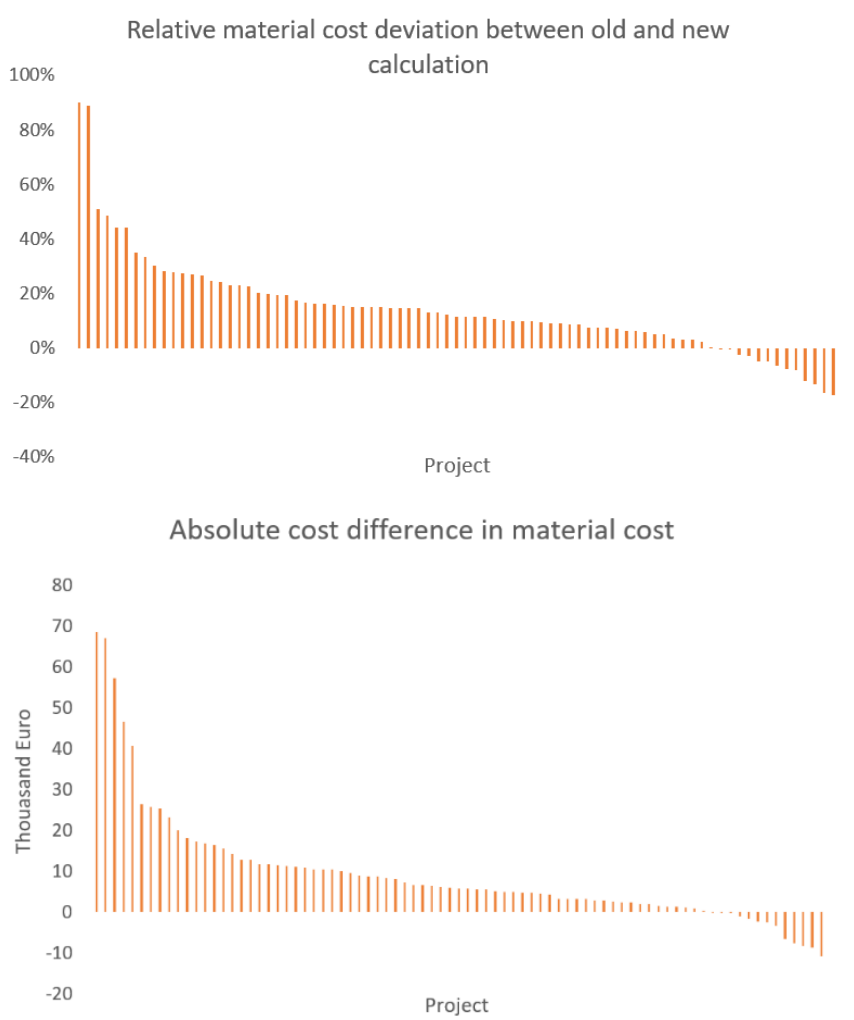

Figure 6. Absolute and relative material cost deviation of 81 different projects from 2014
The product designs were often more complicated than initially expected, resulting in greater material use. A few projects deviated significantly due to unforeseen circumstances that might not have been possible to consider in the PCS in their first occurrence. However, after a while, the costs were settled, and most of the project deviations ranging from $5 \%$ to $25 \%$ could have been reduced or greatly mitigated by a PCS updated as soon as the company gained experience with specific challenges.

\subsubsection{Subcontractor costs}

The cost element that experienced the biggest cost increase $(43 \%)$ was that of subcontractor costs (Figure 7 ). For this increase, as for those of other cost elements, the most drastic cases (deviations above 100\%) were not necessarily preventable, as they tended to be projects that were ongoing during the market changes. However, later projects could have used a new cost structure reflecting the nearly $50 \%$ cost increase for most subcontractors. The subcontractors' role was partly to deliver external approvals of calculations and construction principles, which sometimes resulted in product redesign and, therefore, increased costs in other categories. Additionally, a single large expense was not correctly registered in the 2013 PCS and often overlooked by the salespeople, resulting in additional discrepancies between selling prices in the 2013 PCS and the 2016 PCS.

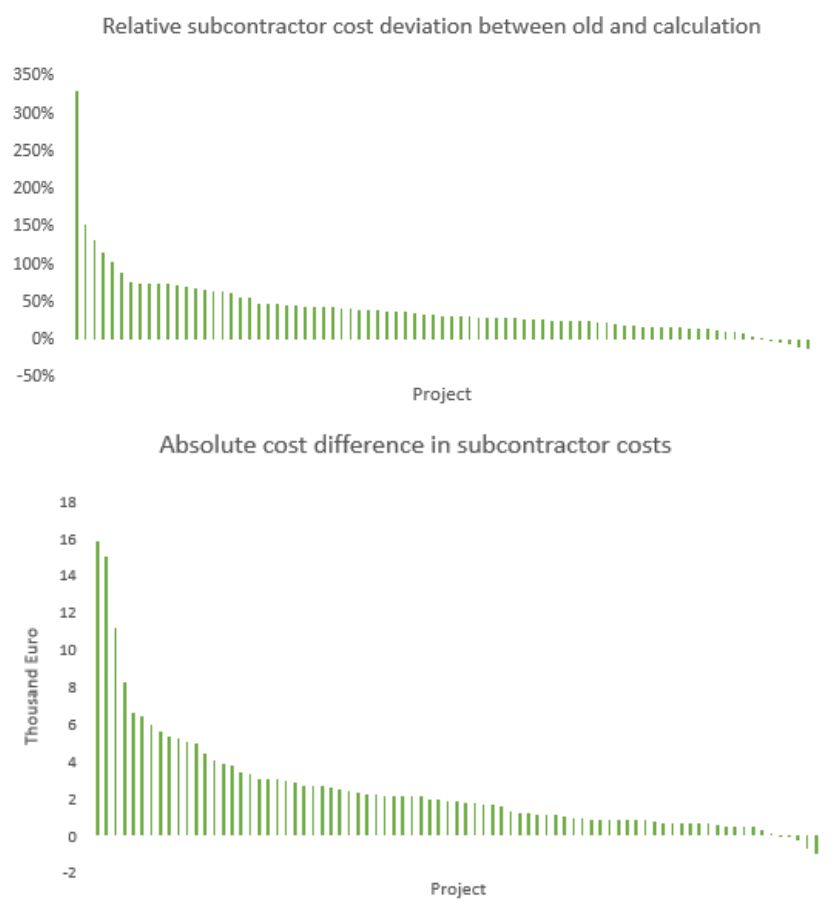

Figure 7. Absolute and relative subcontractor cost deviations of 81 different projects from 2014

\subsubsection{Shared costs}

The deviation in shared costs, or costs shared among customers buying an installation, was directly influenced by the other cost increases (Figure 8). The biggest contribution to shared costs was the miscalculation of the process time to perform the installation, which, in turn, 
resulted in increased salaries and an extended need to rent and allocate machinery for installations. Another contributing factor was the oversimplicity of some sold installations, which further increased the time needed to perform the installation.

Relative shared cost deviation between old and new calculation

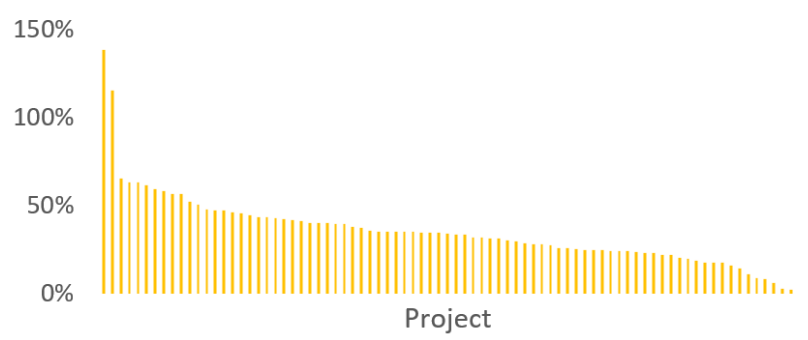

Absolute cost difference in shared cost

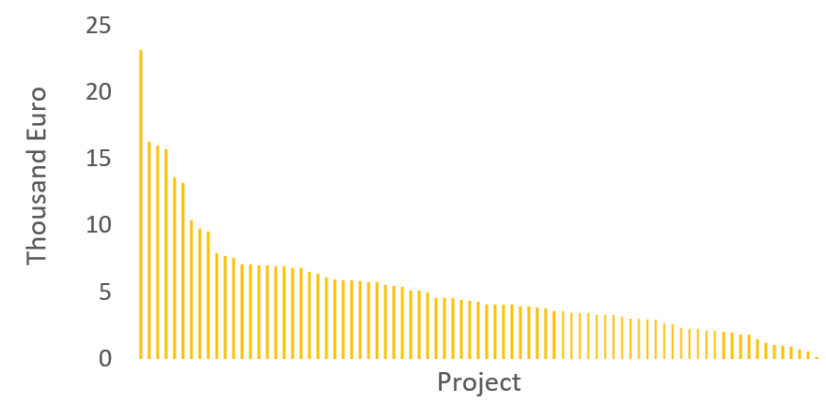

Figure 8. Absolute and relative shared cost deviations of 81 different projects from 2014

\subsection{Cost of PCS ownership and maintenance in relation to potential financial loss}

This section answers the second research question: How do the cost implications compare to the cost of PCS ownership and maintenance? The original PCS was developed in 2007 and fully implemented in 2009, and it cost $150,000 €$ to develop, including work hours for internal and external consultants, software licenses, training, and implementation in existing IT systems. This was a one-time development cost (Figure 9, 2007). The yearly cost of maintenance was calculated by summing the costs of the annual software license (4000 $€)$, the support agreement with the PCS supplier (3300 €), an estimate of the hours spent on internal configuration $(18,500 €)$, and the hours spent by different experts for change validation and ongoing development of product assortments $(12,800 €)$, resulting in a yearly cost of ownership and maintenance of $38,600 €$

After the employee responsible for internal configuration left the company in 2012, the costs for software and support agreement continued, but internal hours were eliminated, resulting in a yearly cost of $7,300 €$ for ownership and maintenance. As the company began to pay more attention to the PCS, it slowly ramped up its culture of on-going development using company experts, resulting in a slow increase in costs for internal hours. A visual representation of the yearly maintenance costs is presented in Figure 9. In 2015, a new update was performed through a collaboration between internal and external consultants to correct the most severe problems. It was estimated to cost approximately 10,000 $€$ in development hours. As the need for a new PCS emerged, the new system was initiated and finished in 2016 at a total cost of $300,000 €$, including significant updates to cost transparency, maintainability, and ability to integrate the PCS with other IT systems. Total investment in the PCS is plotted on a timeline in Figure 9. The accumulated total costs of maintenance and development for both PCSs amount to 784,900 $€$. The majority of this total was spent on new developments $(450,000 €)$, compared to ongoing licenses and maintenance hours $(334,900 €)$. The total cost of ownership was calculated by summing all the lifetime costs, including the costs of development in 2007 and 2016 and the yearly maintenance expenses for the years for which the system has been in use $(784,900 €)$.

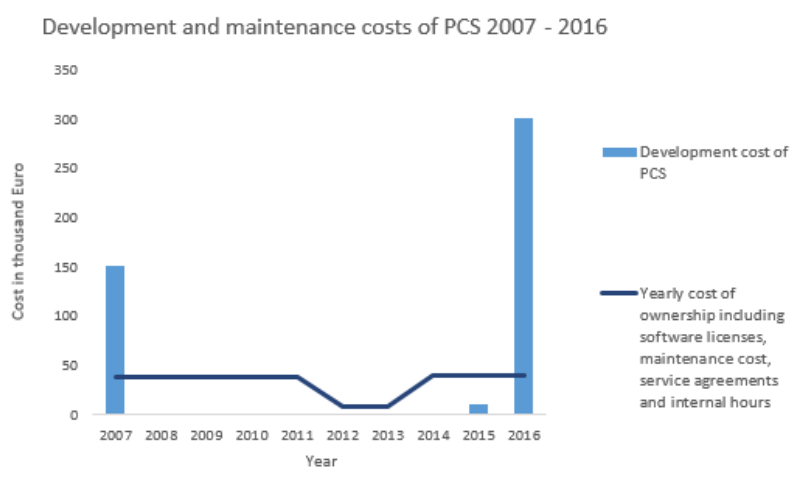

Figure 9. Graphical representation of development and yearly cost of PCS ownership from 2007 to 2016.

The difference between the PCS last updated in 2013 and the 2016 PCS was substantial, with a total miscalculation of $4.27 \mathrm{M} €$. Compared to the cost of this miscalculation, the total cost of PCS development and ownership (Figure 10), including maintenance, was only approximately $18 \%$.

\section{Cost of ownership vs. potential financial loss of miscalculation}

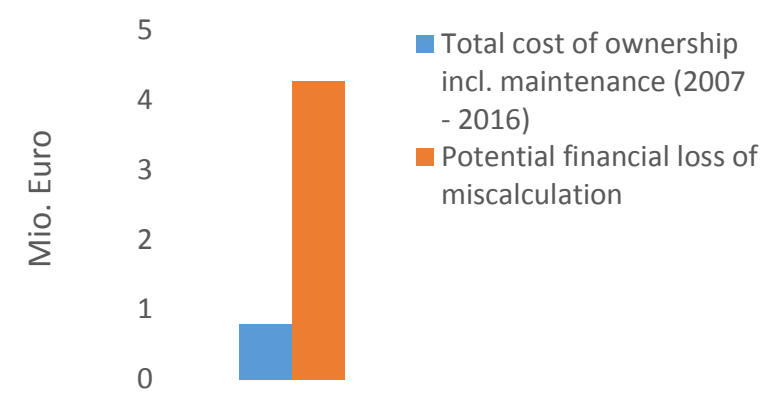

Figure 10. Total cost of PCS ownership, including development and maintenance, over a nine-year period compared to the consequences of 81 miscalculated projects 


\subsection{Reasons for deviations according to the case company}

To understand the deviations and miscalculations in the different projects and cost elements, semi-structured interviews were conducted with the head of sales. The head of sales explained that the company had experienced several rapid changes in requirements due to increased competition, a focus on the company's market, and impacts on society at large. The increased focus hindered project execution for some time, essentially leaving the company with no permissions to perform installations as usual. This period, during which there was a lack of projects to execute, required the company to adapt and make rapid changes in product and production processes. The company's focus was, therefore, on improving the immediate situation. As a result, unfortunately, the company did not pay enough attention to the rising costs of the projects being sold during the time of crisis. According to the head of sales, management was aware that the projects would not turn out as profitable as they had in the past, but had not anticipated a $20 \%$ average increase in costs. The head of sales further explained numerous specific problems related to the different miscalculations between the new and old PCS and the specificities of products not considered during the sales phase, mentioning that some prices were raised in another department and never changed in the PCS. As soon as the company became aware that it was selling products at prices far lower than the costs of the actual product designs, initiatives were taken to improve the PCS. However, the project of improving the PCS took longer than anticipated. The head of sales also mentioned that the company might not have been consistent enough to follow up on all projects, since the company had historically been very successful and close to target on most projects. The company's customers were typically not very price sensitive due to the company's strong brand and reputation as a trusted partner. It was difficult for the head of sales to predict what would have happened to turnover if the prices had been updated earlier; however, the company likely would not have regretted having fewer projects with better profitability.

\section{DISCUSSION AND CONCLUSIONS}

This case study has presented the potential consequences of not updating a PCS in a timely manner. The case study presented a year's worth of projects calculated in a PCS that was not sufficiently maintained and re-calculations in a new PCS reflecting more accurate cost estimates. The total miscalculation in a one-year period was $4.2 \mathrm{M} €$, corresponding to a $20 \%$ increase in total costs and a markedly worse contribution for each project. An investigation of the individual cost elements revealed that they varied for different reasons. This finding aligns with the literature indicating that change drivers come from different sources, both internal and external [29]. In this case, there were two external reasons that could not have been entirely mitigated and several internal reasons related to the lack of maintenance that could have been mitigated. It was observed that the benefits of the PCS reported by the literature are not without risks and that the positive impact of using a PCS is related to the accuracy of the data used [19]. If a company relies too much on a PCS and neglects to update it as products change, the negative implications can be significant. In this case, the company could have saved significant money by updating the PCS earlier than it did. The money lost due to the lack of focus on the PCS in this case study could easily finance a dedicated employee to ensure that the PCS is updated to reflect the most current prices at all times. Additionally, one takeaway of the case is that short-term PCS success is no guarantee of long-term benefits if insufficient attention is given to the system's maintenance. These findings are in line with the literature $[28,50]$ regarding the importance of having valid and accurate master data, and they also provide a quantitative view on the costs of not having such data.

The presented study is based on a single case, which clearly limits the generalizability of the findings. However, due to the close link between critical early product design decisions and fixed prices for customers it is believed that this case material explains a mechanism that stresses the importance of maintaining sales configurators. This research is the first step in quantifying the cost of not maintaining a PCS. To improve this research, more years should be analyzed to investigate long-term trends and gain a deeper understanding of the consequences of not maintaining a PCS. The cost of not maintaining seems to have significant impact on company performance; however, more research is needed to confirm the generalizability of this phenomenon. Another topic worthy of investigation is the trade-off between the cost of maintenance and cost of not maintaining PCSs.

\section{REFERENCES}

[1] Barker, V.E., O'Connor, D.E., Bachant, J. and Soloway, E. (1989), "Expert systems for configuration at Digital: XCON and beyond", Communications of the ACM, Vol. 32, No. 3, pp. 298-318.

[2] Haug, A., Hvam, L. and Mortensen, N.H. (2011), "The impact of product configurators on lead times in engineering-oriented companies", Artificial Intelligence for Engineering Design, Analysis and Manufacturing, Vol. 25, No. 2, pp. 197-206.

[3] Forza, C. and Salvador, F. (2002), "Managing for variety in the order acquisition and fulfilment process: The contribution of product configuration systems", International Journal of Production Economics, Vol. 76, No. 1, pp. 87-98.

[4] Hvam, L., Haug, A., Mortensen, N.H. and Thuesen, C. (2013), "Observed benefits from product configuration systems", International Journal of Industrial Engineering-Theory Applications and Practice, Vol. 20, No. 5-6, pp. 329-338.

[5] Heiskala, M., Paloheimo, K.-S. and Tiihonen, J. (2005), "Mass customisation of services: Benefits and challenges of configurable services", Frontiers of E-Business Research, pp. 206-221.

[6] Heiskala, M. (2007), 'Mass customization with configurable products and configurators', in Mass Customization Information Systems in Business, IGI Global, pp. 1-32.

[7] Hvam, L., Riis, J. and Mortensen, N.H. (2008), Product Customization, Springer, Berlin Heidelberg, Germany.

[8] Forza, C. and Salvador, F. (2007), Product information management for mass customization. Palgrave Macmillan, New York, NY.

[9] Felfernig, A., Friedrich, G. E. and Jannach, D. (2000), "UML as domain specific language for the construction of knowledgebased configuration systems", International Journal of Software Engineering and Knowledge Engineering, Vol. 10, No. 4, pp. 449469 . 
[10] Tiihonen, J., Lehtonen, T., Soininen, T., Puikkinen, A., Sulonen, R. and Riitahuhta, A. (1998), "Modeling configurable product families", in 4th WDK Workshop on Product Structuring, Delft University of Technology, Delft, The Netherlands, pp. 1-22.

[11] Heiskala, M., Tiihonen, J., Sievänen, M. and Paloheimo, K.S. (2010), "Modeling concepts for choice navigation of mass customized solutions", International Journal of Industrial Engineering and Management, Vol. 1, No. 3, pp. 97-103.

[12] Kristjansdottir, K., Shafiee, S. and Hvam, L. (2017), "How to identify possible applications of product configuration systems in engineer-to-order companies", International Journal of Industrial Engineering and Management, Vol. 8, No. 3, pp. 157-165.

[13] Myrodia, A., Kristjansdottir, K. and Hvam, L. (2017), "Impact of product configuration systems on product profitability and costing accuracy", Computers in Industry, Vol. 88, pp. 12-18.

[14] Felfernig, A., Hotz, L., Bagley, C. and Tiihonen, J. (2014), "Benefits of configuration systems", in Knowledge-Based Configuration: From Research to Business Cases, pp. 29-33.

[15] Kristjansdottir, K., Shafiee, S., Hvam, L., Forza, C., and Mortensen, N.H. (2018), "The main challenges for manufacturing companies in implementing and utilizing configurators", Computers in Industry, Vol. 100, pp. 196-211.

[16] Shafiee, S., Hvam, L., Haug, A., Dam, M. and Kristjansdottir, K. (2017), "The documentation of product configuration systems: $A$ framework and an IT solution", Advanced Engineering Informatics, Vol. 32, pp. 163-175.

[17] Zhang, L.L. and Helo, P.T. (2015), "An empirical study on product configurators' application: Implications, challenges and opportunities", in CEUR Workshop Proceedings, pp. 5-10.

[18] Kristjansdottir, K., Shafiee, S., Hvam, L., Bonev, M., and Myrodia, A. (2018), "Return on investment from the use of product configuration systems-A case study", Computers in Industry, Vol. 100, pp. 57-69.

[19] Byrd, T.A., Thrasher, E.H., Lang, T. and Davidson, N.W. (2006), "A process-oriented perspective of IS success: Examining the impact of IS on operational cost", Omega, Vol. 34, No. 5, pp. 448460.

[20] Suzić, N., Forza, C., Trentin, A. and Anišić, Z.. (2018), "Implementation guidelines for mass customization: Current characteristics and suggestions for improvement", Production Planning \& Control, Vol. 29, No. 10, pp. 856-871.

[21] Shafiee, S., Kristjansdottir, K. and Hvam, L. (2017), "Automatic identification of similarities across products to improve the configuration process in ETO companies", International Journal of Industrial Engineering and Management (IJIEM), Vol. 8, No. 3, pp. 167-176.

[22] Myrodia, A., Randrup, T. and Hvam, L. (2018), "Configuration lifecycle management-An assessment of the benefits based on maturity", in Felfernig, A. et al. (Eds.), Proceedings of the 20th International Configuration Workshop, Graz, Austria, pp. 119124.

[23] Kans, M. (2013), "IT practices within maintenance from a systems perspective Study of IT utilisation within firms in Sweden", Journal of Manufacturing Technology Management, Vol. 24, No. 5, pp. 768-791.

[24] Lientz, B.P., Swanson, E.B. and Tompkins, G.E. (1978), "Characteristics of application software maintenance", Communications of the ACM, Vol. 21, No. 6, pp. 466-471.

[25] Kumar, G. and Bhatia, P.K. (2014), "Comparative analysis of software engineering models from traditional to modern methodologies", in 2014 Fourth International Conference on Advanced Computing \& Communication Technologies, IEEE, pp. 189-196.

[26] Shafiee, S., Hvam, L. and Bonev, M. (2014), "Scoping a product configuration project for engineer-to-order companies", International Journal of Industrial Engineering and Management, Vol. 55, No. 4, pp. 207-220.

[27] Prochazka, J. (2011), "Agile support and maintenance of IT services", in Information Systems Development, Springer, New York, NY, pp. 597-609.

[28] Haug, A., Zachariassen, F. and Van Liempd, D. (2011), "The costs of poor data quality", Journal of Industrial Engineering and Management, Vol. 4, No. 2, pp. 168-193.

[29] Tiihonen, J., Soininen, T., Männistö, T. and Sulonen, R. (1996), "State-of-the-practice in product configuration-A survey of 10 cases in the Finnish industry", in Tomiyama, T., Mäntylä, M., and Finger, S. (Eds.), Knowledge Intensive CAD, Chapman \& Hall, pp. 95-114.
[30] Chapin, N. (2000), "Software maintenance types-a fresh view", in Proceedings International Conference on Software Maintenance (ICSM'00), IEEE Computer Society Press, pp. 247-252.

[31] O'Regan, G. (2017), "Capability maturity model integration", in Concise Guide to Software Engineering, Springer International Publishing, pp. 255-277.

[32] Glass, R.L. (2001), "Frequently forgotten fundamental facts about software engineering", IEEE Software, Vol. 18, No. 3, pp. 112114

[33] Haug, A., Hvam, L. and Mortensen, N. H. (2012), "Definition and evaluation of product configurator development strategies", Computers in Industry, Vol. 63, No. 5, pp. 471-481.

[34] Blecker, T., Abdelkafi, N., Kaluza, B. and Friedrich, G. (2006), "Controlling variety-induced complexity in mass customisation: a key metrics-based approach", International Journal of Mass Customisation, Vol. 1, No. 2-3, pp. 272-298.

[35] Felfernig, A., Friedrich, G., Jannach, D. and Stumptner, M. (2004), "Consistency-based diagnosis of configuration knowledge bases", Artificial Intelligence, Vol. 152, No. 2, pp. 213-234.

[36] Ballou, D., Madnick, S. and Wang, R. (2003), "Assuring information quality", Journal of Management Information Systems, Vol. 20, No. 3, pp.9-11.

[37] Wang, R.Y. and Strong, D.M. (1996), "Beyond accuracy: What data quality means to data consumers", Journal of Management Information Systems, Vol. 12, No. 4, pp. 5-34.

[38] Madnick, S., Wang, R. and Xian, X. (2003), "The design and implementation of a corporate householding knowledge processor to improve data quality", Journal of Management Information Systems, Vol. 20, No. 3, pp. 41-70.

[39] Haug, A., Stentoft Arlbjørn, J. and Pedersen, A. (2009), "A classification model of ERP system data quality", Industrial Management \& Data Systems, Vol. 109, No. 8, pp. 1053-1068.

[40] Batini, C., Cappiello, C., Francalanci, C. and Maurino, A. (2009), "Methodologies for data quality assessment and improvement", ACM Computing Surveys, Vol. 41, No. 3, Article number 16.

[41] Even, A. and Shankaranarayanan, G. (2009), "Utility cost perspectives in data quality management", Journal of Computer Information Systems, Vol. 50, No. 2, pp. 127-135.

[42] Ryu, K.S., Park, J.S. and Park, J.H. (2006), "A data quality management maturity model", ETRI Journal, Vol. 28. No. 2, pp. 191-204.

[43] Even, A. and Shankaranarayanan, G. (2007), "Utility-driven configuration of data quality in data repositories", International Journal of Information Quality, Vol. 1, No. 1, p. 22-40.

[44] Capretz, M.A.M. and Munro, M. (1994), "Software configuration management issues in the maintenance of existing systems", Journal of Software Maintenance: Research and Practice, Vol. 6, No. 1, pp. 1-14.

[45] Haug, A. and Hvam, L. (2007), "The modeling techniques of a documentation system that supports the development and maintenance of product configuration systems", International Journal of Mass Customisation, Vol. 2, No. 1/2, pp. 1-18.

[46] Pui Ng, C.S., Gable, G. and Chan, T. (2003), "An ERP maintenance model", in Proceedings of the $36^{\text {th }}$ Annual Hawaii International Conference on System Sciences, Big Island, USA, p. 1-10.

[47] Law, C.C.H., Chen, C.C. and Wu, B.J.P. (2010), "Managing the full ERP life-cycle: Considerations of maintenance and support requirements and IT governance practice as integral elements of the formula for successful ERP adoption", Computers in Industry, Vol. 61, No. 3, pp. 297-308.

[48] Salmeron, J.L. and Lopez, C. (2010), "A multicriteria approach for risks assessment in ERP maintenance", The Journal of Systems \& Software, Vol. 83, No. 10, pp. 1941-1953.

[49] Müller, P. (2013), "Configuration management-A core competence for successful through-life systems engineering and engineering services", Procedia CIRP, Vol. 11, pp. 187-192.

[50] Marsh, R. (2005), "Drowning in dirty data? It's time to sink or swim: A four-stage methodology for total data quality management", Journal of Database Marketing \& Customer Strategy Management, Vol. 12, No. 2, pp. 105-112.

[51] Kim, W. and Choi, B. (2003), "Towards quantifying data quality costs", The Journal of Object Technology, Vol. 2, No. 4, p. 69-76.

[52] Eppler, M.J. and Helfert, M. (2004), "A classification and analysis of data quality costs", in Proceedings of the Ninth International Conference on Information Quality (ICIQ-04), pp. 311-325.

[53] Benbasat, I., Goldstein, D.K. and Mead, M. (1987), "The case research strategy in studies of information systems", MIS 
Quarterly, Vol. 11, No. 3, pp. 369-386.

[54] Voss, C., Tsikriktsis, N. and Frohlich, M. (2002), "Case research in operations management", International Journal of Operations \& Production Management, Vol. 22, No. 2, pp. 195-219.

[55] Meredith, J. (1998), "Building operations management theory through case and field research", Journal of Operations
Management, Vol. 16, No. 4, pp. 441-454.

[56] McCutcheon, D.M. and Meredith, J.R. (1993), "Conducting case study research in operations management", Journal of Operations Management, Vol. 11, No. 3, pp. 239-256.

\title{
Troškovi neodržavanja sistema za konfigurisanje proizvoda
}

\author{
Jeppe Bredahl Rasmussen, Anna Myrodia, Lars Hvam, Niels Henrik Mortensen
}

Primljen (26.10.2018.); Recenziran (27.11.2018.); Prihvaćen (05.12.2018.)

\section{Rezime}

Ovaj rad istražuje uticaj korišćenja nedovoljno održavanog sistema za konfigurisanje proizvoda (PCS) na troškove. Finansijski gubitak zbog lošeg kvaliteta podataka u proizvodima koji se prodaju putem neodržavanih PCS-a ispitan je kroz studiju slučaja. Finansijski gubitak je izračunat upoređivanjem, za isti proizvod, ponuda koje su generisane kroz neodržavan PCS sa ponudama generisanim kroz ažurirani PCS. Rezultati su pokazali da je preduzeće prodavalo proizvode sa pogrešom procenom troškova - $20 \%$ nižom od stvarne vrednosti. Poređenjem nastalog finansijskog gubitka sa troškovima ažuriranja PCS, pokazalo se je da je prvi znatno veći od drugog. Zaključak rada je da ostvareni uspesi i koristi od primene PCS-a u mnogome zavise od održavanja PCS-a i kvaliteta podataka koji se koriste.

Ključne reči: Sistem za konfigurisanje proizvoda, preciznost izračunavanja troškova, prednosti sistema za konfigurisanje proizvoda, izazovi sistema za konfigurisanje proizvoda, studija slučaja 